Egyptian Journal of Aquatic Biology \& Fisheries

Zoology Department, Faculty of Science,

Ain Shams University, Cairo, Egypt.

ISSN $1110-6131$

Vol. 23(3): 385 -399 (2019)

www.ejabf.journals.ekb.eg

\title{
Physical and chemical characteristics of mangrove soil under marine influence. A case study on the Mangrove Forests at Egyptian-African Red Sea Coast.
}

\author{
Abdelwahab A. Afefe ${ }^{*}$, Mohamed S. Abbas², Amira Sh. Soliman', \\ Abdel-Hamid A. Khedr ${ }^{3}$ and El-Bialy E. Hatab ${ }^{1}$ \\ 1- Nature Conservation Sector, Egyptian Environmental Affairs Agency (EEAA), Egypt. \\ 2- Natural Resources Department, Faculty of African Postgraduate Studies, Cairo \\ University, Egypt. \\ 3-Botany and Microbiology Department, Faculty of Science, Damietta University, Egypt \\ *Corresponding author: abdoafefe@ hotmail.com
}

\section{ARTICLE INFO \\ Article History: \\ Received: July 7, 2019 \\ Accepted: Sept. 6,2019 \\ Online: Sept. 9, 2019}

Keywords:

Mangrove

Red Sea

Soil

Protected Area

Avicennia marina

Rhizophora mucronata.

\begin{abstract}
The present study provides an analysis the growth performance of mangrove forests (Avicennia marina and Rhizophora mucronata) and the concentrates on the environmental factors (soil) that affect on the mangroves along Egyptian-African Red Sea coast. The growth performance of $R$. mucronata was higher in association with A. marina than in pure stands. Moreover, A. marina trees growing in association with $R$. mисronata were taller than plants growing in pure community. Plants growing (size index) at high tide attained the highest values of growth attributes. In comparison, A. marina growth attributes differed between the three locations of the three tide levels. The highest values of the growth parameters were recorded for A. marina growing at the medium tide in pure stands. However, the growth values of A. marina growing in mixture with $R$. mucronata were higher at low tide than those at either high or medium tides. The total mean of Soil Bulk Density (SBD) of the A. marina $(1.24 \mathrm{~g}$ $\left.\mathrm{cm}^{3}\right)$ was higher than that of the $R$. mucronata $\left(1.16 \mathrm{~g} \mathrm{~cm}^{3}\right)$ and mixed stands $\left(1.12 \mathrm{~g} \mathrm{~cm}^{3}\right)$. The results shows that both ordination techniques clearly indicated that electric conductivity, $\mathrm{CaCO} 3, \mathrm{~K}+, \mathrm{Ca}++, \mathrm{Cl}-, \mathrm{Na}+$ and $\mathrm{Mg}++$ were the most important parameters determining the current distribution of mangrove pattern in the Egyptian Red Sea coast. The results showed that there is a similarity between the soil samples in different of the study locations as whole area is a coastal. In the current study the variability of ecosystem structure and function is generally a product of interactions between its different components. In the extreme arid environmental conditions of arid lands these interactions are of high significance, so that slight irregularities in one component of the ecosystem are likely to lead to substantial variations in others, so creating distinct micro habitats.
\end{abstract}

\section{INTRODUCTION}

Mangrove forests are tropical trees and woody shrubsgrowing at the intertidal zone of highly productive ecosystem of the tropical and subtropical regions (Kathiresan and Bingham, 2001; Giri et al., 2011). Mangrove forests cover approximately $137,760 \mathrm{~km}^{2}$ worldwide (Giriet al. 2011) and are more productive in terms of net primary production than most other types of forests. 
These ecosystems provide coastal protection, habitat, shelter, nursery and breeding grounds for many fish and crustacea, and other sea and terrestrial fauna (Alongi et al., 2004; FAO, 2005). $R$. mucronata is a small to medium size evergreen tree growing to a height of about 10 or 15 metres as average on the fringes of the sea. The tallest trees are closest to the water and shorter trees are further inland. The tree has a large number of aerial stilt roots buttressing the trunk. The leaves are elliptical and usually about $12 \mathrm{~cm}$ long and $6 \mathrm{~cm}$ wide. They have elongated tips but these often break off. There are corky warts on the pale undersides of the leaves. The flowers develop in axillary clusters on the twigs. Each has a hard cream-coloured calyx with four sepals and four white, hairy petals. The seeds are viviparous and start to develop whilst still attached to the tree (Gillikin and Verheyden, 2005). Where, the A. marina is a small shrub/tree with long creeping roots which give out at intervals narrow negatively geotrophic pneumatophores / respiratory roots. Leaves opposite, entire, ovate to oblanceolate, glabrous. Flowers small, yellow, sessile, in axillary and terminal cymes. Fruit a compressed ovoid capsule, dehiscing by 2 leathery valves (Gamble, 1921).

The mangroves in Egypt occupy about 525 hectares distributed in 28 different locations along Egyptian Red Sea coasts. One large discontinuous stand along the Gulf of Aqaba in Nabq Protected Area and one small stand at the most southern part of Gulf of Suez at Ras Mohammed National Park (Zahran and Willis, 2009). Mangroves in Egypt are predominantly mono-specific, consisting only of Avicennia marina (grey mangroves; Avicenniaceae), except for a few locations near the Egyptian-Sudanese border area, where Rhizophora mucronata (loop-root mangrove; Rhizophoraceae) coexists along with A. marina. From a geographical point of view, the Egyptian mangroves can be divided into the Sinai mangroves, and mangroves growing on the Egyptian-African Red Sea coast (PERSGA, 2004). A. marina is relatively more tolerant and adapted to salinity, low rainfall and extreme temperature conditions than $R$. mucronata. This explains the larger global and local (in Egypt) distribution of $A$. marina than $R$. mucronata.

$R$. mucronata exists in Egypt onlyin few localities around the EgyptianSudanese border area (Particularly in MarsaSha'ab and Marsa Abu Fassi), the distribution of mangroves in the southern Red Sea is more continuous than in the northern Red Sea (Aqaba Gulf) where mangroves are confined to a very restricted favorable habitats (Zahran and Willis, 2009). The mangroves export organic nutrients whereas saltmarsh and fringe communities act as nutrient sinks (Clarke, 1985). The above ground mangrove biomass correlated significantly with soil factors (Boto and Wellington, 1984). Many marsh soils contain large amount of sulphur which is oxidized to sulphate when exposed to air (Cotnoir, 1974). Mangrove soils generally were high in clay, organic matter, cation exchange capacity, $\mathrm{Al}, \mathrm{SO} 4, \mathrm{Fe}$ and exchangeable bases than non- mangrove soils. On the basis of exchangeable $\mathrm{Na}$ percentage and electrical conductivity, mangrove soils are classified as saline sodic and the non-mangrove soil, nonsaline sodic (Naidoo and Raiman, 1982). Studies of mineral elements in the mangroves from saline and non-saline localities reveal that potassium uptake is considerably reduced which results in increased uptake of calcium. Potassium and calcium ions build up salt tolerance in mangroves. However sodium concentration affects calcium uptake much more than that of potassium (Joshi and Jamale, 1975). Zahran and Al-Kaf (1996) reportd that, the halophytes were grouped under 6 types: seagrasses, mangroves, salt marshes, sand dunes, reed swamps and palm groves. Climate is arid, hot and dry soil is sandy, saline and contains more calcium carbonates. In an estuarine mangrove swamp in Africa, 
Ukpong (1998) reported high soil cation exchange capacity (21.8 to 53.6 me times $100 \mathrm{~g}$ super $\left({ }^{-1}\right)$, with $\mathrm{Mg}$ and $\mathrm{Ca}$ as the predominant cations. Soil nutrient content was related to tidal inundation, physiography, climate and soil drainage. The depth distribution of total $\mathrm{Al}, \mathrm{Fe}, \mathrm{Mn}, \mathrm{Zn}, \mathrm{Cu}, \mathrm{Cd}, \mathrm{Pb}, \mathrm{Ca}, \mathrm{Mg}$ and nitrogen were determined in sediment cores from a series of stations in the Tudor, Makupa and Gazi creeks of the Kenyan coast of the Indian ocean (Oteko, 1987).

The objective of the present study is analysis the growth performance of mangrove forests (Avicennia marina and Rhizophora mucronata) with the concentration of the environmental factors (physical and chemical analysis of the soil) that affect on the mangroves in Elba Protected Area along Egyptian-African Red Sea coast.

\section{MATERIALS AND METHODS}

\section{STUDY AREA}

Gebel Elba Protected Area is located between the longitudes $22^{\circ} 00 ' \mathrm{~N}$ $23^{\circ} 50^{\prime} \mathrm{N}$, and thelatitudes $35^{\circ} 00^{\prime} \mathrm{E}-37^{\circ} 00^{\prime} \mathrm{E}$, with a totalarea of about $35,600 \mathrm{~km}^{2}$. It is the largest declared protected area in Egypt. Gebel Elba is a part of the Egyptian deserts that is considered as one of the most extremely arid areas of the world. The recorded mean minimum temperature is $11.4 \mathrm{C}^{\circ}$ during January, while, the recorded maximum temperature is $38.7 \mathrm{C}^{\circ}$ in July. The area is almost rainless, with a mean annual precipitation of $27.8 \mathrm{~mm}$. The relative humidity shows that the atmosphere is dry throughout the year ( $\mathrm{RH}=47.2 \%$ to $60 \%$ ) (GEPA, 2008). Field sites were located at the south of Shalateencity to the north of Abu Ramad village. Sampling was carried out in three main mangrove locations to represent the mangrove forests along the Egyptian Red Sea Coast (Figure 1). Sharm El Madfaa $\left(9.2 \mathrm{~km}^{2}\right)$, MarsaSha'ab $\left(15.8 \mathrm{~km}^{2}\right)$ and Marsa Abu Fassi $\left(0.7 \mathrm{~km}^{2}\right)$ (ITTO, 2006). Mangrove species composition at each location was determined (either A. marina or $R$. mucronata) (Table 1).

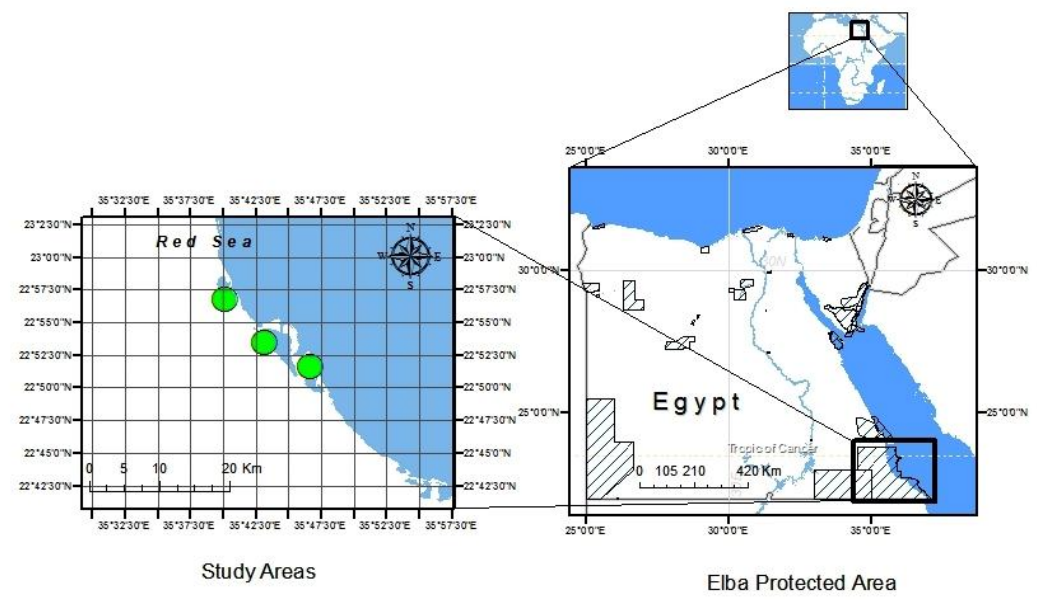

Fig. 1. Map of Egypt and the Elba Protected Area showing the study sites.

\section{THE STUDY SPECIES}

The mangrove stands along the Gulf of Aqaba and the Egyptian Red Sea coastlines cover a total area exceeding 525 hectares (Zahran and Willis, 2009). They are predominantly mono specific, consisting only of Avicennia marina, except for a few stands in the southern Sudanese border area where Rhizophora mucronata coexists along with Avicennia marina. From a geographical point of view, the 
Egyptian mangroves may be divided into the Sinai mangroves and mangroves growing on the Egyptian-African Red Sea coast (PERSGA, 2004).

Table 1: The study samples collected within the study area.

\begin{tabular}{lllll}
\hline Site No. & \multicolumn{1}{c}{ Species } & \multicolumn{1}{c}{ Study site } & Lat & \multicolumn{1}{c}{ Long } \\
\hline 1 & A.marina & Sharm EL Madfaa & 22.94527 & 35.66717 \\
2 & A.marina & Sharm EL Madfaa & 22.94519 & 35.66753 \\
3 & A.marina & Sharm EL Madfaa & 22.94474 & 35.66766 \\
4 & A.marina + R.mucronata & MarsaSha'ab & 22.89105 & 35.71787 \\
5 & A.marina+ R.mucronata & MarsaSha'ab & 22.89001 & 35.71856 \\
6 & A.marina + R.mucronata & MarsaSha'ab & 22.89004 & 35.71353 \\
7 & R.mucronata & MarsaSha'ab & 22.89048 & 35.7182 \\
8 & R.mucronata & MarsaSha'ab & 22.88851 & 35.72582 \\
9 & R.mucronata & MarsaSha'ab & 22.88859 & 35.72579 \\
10 & A.marina & MarsaSha'ab & 22.88118 & 35.72708 \\
11 & A.marina & MarsaSha'ab & 22.88105 & 35.72723 \\
12 & A.marina & MarsaSha'ab & 22.88319 & 35.72695 \\
13 & A.marina & MarsaSha'ab & 22.85823 & 35.77554 \\
14 & A.marina & MarsaSha'ab & 22.85873 & 35.77548 \\
15 & A.marina & MarsaSha'ab & 22.85829 & 35.77619 \\
16 & R.mucronata & Marsa Abu Fassi & 22.85175 & 35.77638 \\
17 & R.mucronata & Marsa Abu Fassi & 22.85181 & 35.77695 \\
18 & R.mucronata & Marsa Abu Fassi & 22.85174 & 35.77639 \\
19 & A.marina R.mucronata & Marsa Abu Fassi & 22.85184 & 35.77658 \\
20 & A.marina+ R.mucronata & Marsa Abu Fassi & 22.85184 & 35.7766 \\
21 & A.marina+R.mucronata & Marsa Abu Fassi & 22.85183 & 35.77661 \\
22 & A.marina & Marsa Abu Fassi & 22.84961 & 35.7797 \\
23 & A.marina & Marsa Abu Fassi & 22.85008 & 35.78002 \\
24 & A.marina & Marsa Abu Fassi & 22.85068 & 35.78026 \\
\hline & & & &
\end{tabular}

\section{MANGROVE VEGETATION ANALYSIS}

Mangrove stands was observed at this sites during June, 2016 to June, 2017. Sampling was carried out in three main locations (Sharm EL Madfaa, Marsa Sha'ab and Marsa Abu Fassi) included 24 study site in Elba Protected Area to represent the mangrove forests along the Egyptian-African Red Sea Coast. The sampled stations were classified to mangrove $A$. marina and $R$. mucronata.

In each stand three random plots $(10 \times 10 \mathrm{~m})$ were selected for each mangrove type. A plot location was arranged randomly within each strata, plots are picked at random to increase the likelihood of capturing the true variation within and across forest strata (terrestrial side/ middle/ sea side) (Howard et. el., 2014). In each plot, species density, frequency and canopy cover were calculated according to MullerDombois and Ellenberg (1974). The main lateral branches per tree, tree circumference (at d.b.h) and leaf area are measured. Moreover, plant height $(\mathrm{H})$ and diameter (D) of each individual of certain species in the sampled plots were measured and its size index was calculated as follows. [H+D)/2 (Crisp and Lange, 1976).

Soil Samples and Analysis.

The soil samples were collected during the work from all the plots of the study. From each plot three soil samples were collected and mixed to form a composite sample for the determination of their physical and chemical characteristics. The surface samples (excluding the surface crust) were taken to the depth of $25 \mathrm{~cm}$.

Soil Bulk Density (SBD): In each of the main locations, 5 soil samples were collected randomly making a total 120 soil cores to assure representative samples to each of the mangrove species, and to determine SBD. Soil samples were collected with a $7 \mathrm{~cm}$ diameter hand sediment corer, which provides a core without 
compaction, distortion and disturbance (Tan, 2005). The corer was carefully inserted into the soil and pushed down to $50 \mathrm{~cm}$ depth. The soil core was removed from the corer slowly, and it was immediately sectioned with a blade into samples each of 10 $\mathrm{cm}$ thick $(0-10,10-20,20-30,30-40 \mathrm{~cm}$ and $40-50 \mathrm{~cm})$ and packed in plastic containers. Each soil sample was oven-dry at $105{ }^{\circ} \mathrm{C}$ for three days, cooled down to room temperature in a desiccator, and weighed to determine the SBD (Soil Bulk Density) $\left(\mathrm{g} \mathrm{cm}^{-3}\right)$ as follows (Wilke, 2005).

$\rho_{s j}=\frac{m_{j}}{v_{j}}$

Where $\rho_{\mathrm{sj}}$ is $\mathrm{SBD}\left(\mathrm{g} \mathrm{cm}^{-3}\right)$ of the $\mathrm{j}^{\text {th }}$ layer, $\mathrm{m}_{\mathrm{j}}$ is mass of soil sample $(\mathrm{g})$ of the $\mathrm{j}^{\text {th }}$ layer dried at $105^{\circ} \mathrm{C}$ and $v_{j}$ is volume of soil sample $\left(\mathrm{cm}^{3}\right)$ of the $j^{\text {th }}$ layer. Dry samples will ground and sieve to pass through $2 \mathrm{~mm}$ particle size.

Surface soil samples (at depth of $25 \mathrm{~cm}$, excluding the surface crust) were randomly collected at different stands to determine their physical and chemical characteristics.

Physical analysis: soil texture was determined using a series of sieves. Soil samples were air-dried and passed manually through a 2-mm sieve to evaluate gravel percent. Particle size analysis was accomplished according to Piper (1950) to calculate the percentages of sand, silt, and clay and the classification of the soil texture type was accomplished according to the USDA soil texture triangle (USDA, 1993).

Chemical analysis: Calcium carbonate was measured by titration against $1.0 \mathrm{~N} \mathrm{HCl}$ following Allen et al. (1976). Oxidizable organic carbon (as an indication of the total organic matter content) was measured according to (Black, 1965). Soil reaction (pH value), electrical conductivity, sulphates and chlorides were measured according to Jackson (1967). Bicarbonate was determined by titration using $0.1 \mathrm{~N} \mathrm{HCl}$ (Allen et al., 1976). Extractable cations $\left(\mathrm{Ca}^{++}\right.$and $\left.\mathrm{Mg}^{++}\right)$were determined (meq/L) by titration following Richard (1954); while, sodium and potassium ions (meq/L) were measured from air-dried soil using ammonium acetate solution at $\mathrm{pH}=7$ (Allen et al., 1976).

\section{Statistical Analysis.}

One-way analysis of variance (ANOVA-1) was used to identify statistically significant differences in SOC contents and SBD among the two species of mangrove in pure and mixed stands and five soil depths. Significant differences between means among the five soil depths were identified using the least significant difference (LSD) test at $\mathrm{P}<0.05$. Statistical analyses were performed using SPSS 15.0 software (SPSS, 2006).

All ordinations were performed using the CANOCO program (version 4.5); Canoco 4.51 is one of the most popular programs for multivariate statistical analysis using ordination methods in the field of ecology and several related fields. (Ter Braak, 1998; Hejcmanovā-Neźerková and Hejcman, 2006).

\section{RESULTS}

\section{Floristic relations}

In the present study, the growth performance of $R$. mucronata was higher in association with A. marina than in pure stands and A. marina trees growing in association with $R$. mucronata were taller than that growing in pure community. Moreover, the growth attributes (size index) of $R$. mucronata in association with $A$. marina at high tide attained the highest values of growth attributes than of pure community. In comparison, the growth attributes (size index) of A. marina in 
association with $R$. mucronata at low tide attained the highest values of growth attributes then of pure community.

The highest values of the growth parameters were recorded for A. marina growing at the medium tide in mixture with $R$. mucronata. However, the mean comparison of growth performance at the different tides for A. marina and $R$. mucronata can be explainedclearly as shown in Tables 2, 3 and Figure 2.

Table 2: Mean comparison of growth performance of Avicennia marina growing alone (pure) and with Rhizophora mucronata (mixed) at low, medium and high tides

\begin{tabular}{|c|c|c|c|c|c|c|c|c|c|}
\hline \multirow[t]{2}{*}{ Character } & \multicolumn{3}{|c|}{ Pure } & \multicolumn{4}{|c|}{ Mixed } & \multirow[b]{2}{*}{ P-value } & \multirow[b]{2}{*}{ F-value } \\
\hline & Low & Medium & High & Low & Medium & High & Mean & & \\
\hline Height $(\mathrm{cm})$ & 253 & 419 & 224 & 546 & 493 & 280 & 352.57 & .001 & 1.931 \\
\hline Size index & 130.80 & 218.26 & 116.46 & 282.39 & 255.10 & 150.19 & 183.43 & .001 & 2.080 \\
\hline Trunk circumf. $(\mathrm{cm})$ & 8.60 & 17.52 & 8.92 & 18.79 & 17.20 & 20.38 & 14.29 & .001 & 5.391 \\
\hline No. main branches & 5 & 6 & 3 & 13 & 17 & 7 & 8 & .012 & 6.373 \\
\hline No. lateral branches & 23 & 20 & 13 & 24 & 77 & 20 & 28.57 & .028 & 1.356 \\
\hline Leaf number & 1032 & 2744 & 607 & 1976 & 8462 & 7100 & 3279 & .043 & 4.445 \\
\hline No aerial roots & 1832 & 2472 & 958 & 1205 & 1938 & 762 & 1571.29 & .002 & .660 \\
\hline No seedlings & 12 & 29 & 7 & 2 & 5 & 8 & 10.71 & .045 & 2.556 \\
\hline Trees/ha & 500 & 166 & 700 & 300 & 150 & 100 & 345.14 & .021 & 2.654 \\
\hline
\end{tabular}

Table 3: Mean comparison of growth performance of Rhizophora mucronata growing alone (pure) and with Avicennia marina (mixed) at low, medium and high tides

\begin{tabular}{llllllllll}
\hline Character & Pure & \multicolumn{9}{c}{ Mixed } & \multicolumn{1}{c}{} \\
\cline { 2 - 10 } & Low & Medium & High & Low & Medium & High & Mean & P-value & F-value \\
\hline Height $(\mathrm{cm})$ & 325 & 275 & 151 & 431 & 413 & 450 & 338.57 & .001 & 11.746 \\
Size index & 167.44 & 142.12 & 79.00 & 221.07 & 212.55 & 232.32 & 174.56 & .001 & 11.803 \\
Trunk circumf. (cm) & 9.87 & 9.24 & 7.01 & 11.15 & 12.10 & 14.65 & 10.56 & .000 & 8.358 \\
No. main branches & 7 & 5 & 8 & 10 & 5 & 3 & 6.43 & .002 & 0.087 \\
No. lateral branches & 38 & 39 & 17 & 39 & 34 & 21 & 32.29 & .001 & 1.02 \\
Leaf number & 1716 & 798 & 734 & 1023 & 796 & 708 & 1070.14 & .002 & 0.528 \\
No aerial roots & 8 & 9 & 6 & 180 & 33 & 12 & 36.57 & .017 & 4.469 \\
No seedlings & 8 & 4 & 14 & 1 & 9 & 2 & 6.57 & .025 & 1.474 \\
Trees/ha & 650 & 500 & 400 & 150 & 300 & 300 & 421.43 & .003 & 9.143 \\
\hline
\end{tabular}

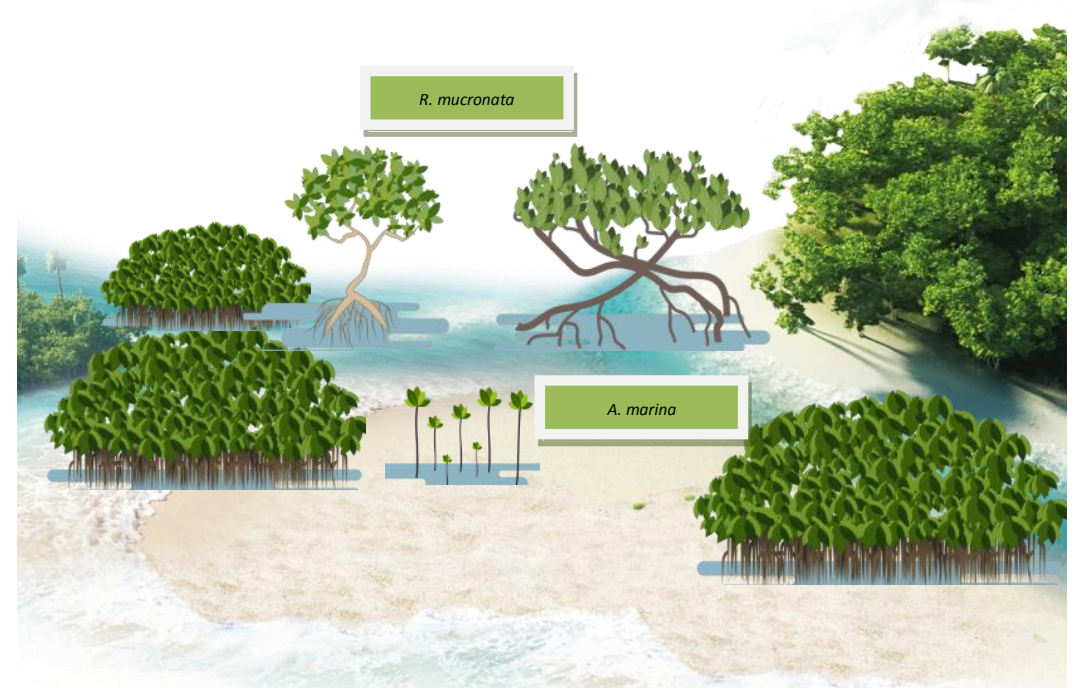

Fig. 2: Diagram showing the common distribution of mangrove trees in mixed communities growing on an extensive inter-tidal flat at the study area. 


\section{Multivariate analysis \\ Classification}

The total mean of Soil Bulk Density (SBD) of the A. marina stands (1.24 g $\left.\mathrm{cm}^{-3}\right)$ was higher than that of the $R$. mucronata stands $\left(1.16 \mathrm{~g} \mathrm{~cm}^{-3}\right)$ and mix stands $\left(1.12 \mathrm{~g} \mathrm{~cm}^{-3}\right)$ (Table 4). The ANOVA test showed significant variation between soil depth layers. For instance, at low depth layer $(0-10 \mathrm{~cm}) A$. marina was significant higher $\left(1.20 \mathrm{~g} \mathrm{~cm}^{-3}\right)$ than $R$. mucronata and mixed stands $\left(1.14 \mathrm{~g} \mathrm{~cm}^{-3}\right.$ and $1.10 \mathrm{~g}$ $\mathrm{cm}^{-3}$ respectively) with $\mathrm{F}$-value $=4.16$ and $p<0.047$ and $p<0.019$ respectively (Figure 3). Moreover, at the depth layer $(10-20 \mathrm{~cm})$ A. marina was significant higher $\left(1.23 \mathrm{~g} \mathrm{~cm}^{-3}\right)$ than $R$. mucronata and mixed stands $\left(1.09 \mathrm{~g} \mathrm{~cm}^{-3}\right.$ and $1.09 \mathrm{~g} \mathrm{~cm}^{-3}$ respectively) with F-value $=5.404$ and $p<0.013$ and $p<0.016$ for $R$. mucronata and mixed stands respectively.

On the other hand, the distribution of SBD in the A. marina stands recorded $1.24 \mathrm{~g} \mathrm{~cm}^{-3}$ at depth $20-30 \mathrm{~cm}$ and recorded $1.34 \mathrm{~g} \mathrm{~cm}^{-3}$ at depth $40-50 \mathrm{~cm}$. While, the distribution of SBD in the R. mucronata stands from $1.12 \mathrm{~cm}^{-3}$ at depth $20-30 \mathrm{~cm}$ up to $1.21 \mathrm{~g} \mathrm{~cm}^{-3}$ at depth $30-40 \mathrm{~cm}$ to $1.25 \mathrm{~g} \mathrm{~cm}^{-3}$ at depth $40-50 \mathrm{~cm}$. However, the range of SBD for mangrove (the two species) in the study area was between $0.95-$ $1.55 \mathrm{~g} \mathrm{~cm}^{-3}$.

Table 4: The total means of Soil Bulk Density (SBD) of A. marina, R. mucronata and mixed stands at different soil depth layers.

\begin{tabular}{ccccccc}
\hline Species & $\mathbf{0 - 1 0} \mathbf{~ c m}$ & $\mathbf{1 0 - 2 0} \mathbf{~ c m}$ & $\mathbf{2 0 - 3 0} \mathbf{~ c m}$ & $\mathbf{3 0 - 4 0} \mathbf{~ c m}$ & $\mathbf{4 0 - 5 0} \mathbf{~ c m}$ & Total Mean \\
\hline A. marina & 1.20 & 1.23 & 1.24 & 1.21 & 1.34 & 1.24 \\
R. mucronata & 1.14 & 1.09 & 1.12 & 1.21 & 1.25 & 1.16 \\
Mixed stands & 1.10 & 1.09 & 1.15 & 1.12 & 1.15 & 1.12 \\
\hline
\end{tabular}

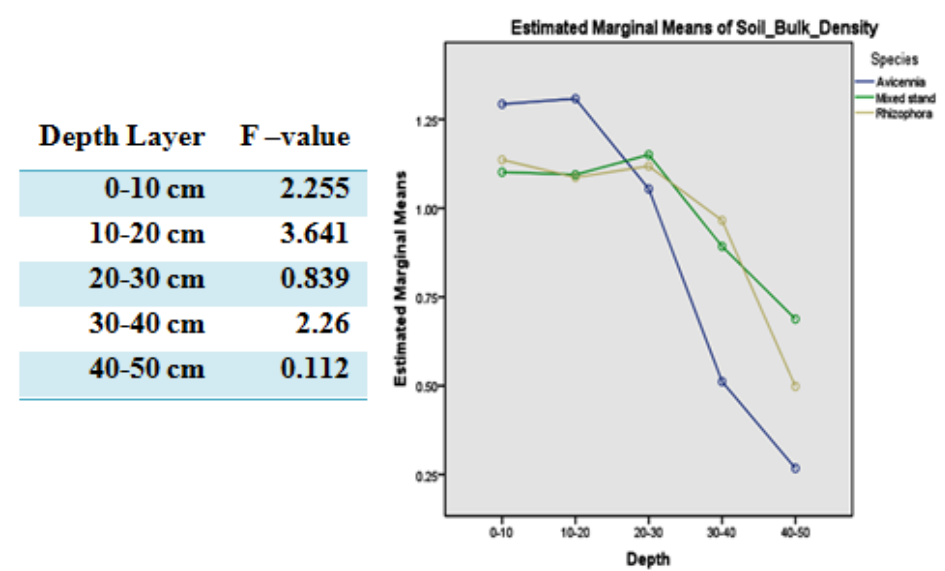

Fig. 3: The ANOVA-1 estimated marginal means of Soil Bulk Density (SBD) of A. marina, $R$. mucronata and mixed stands at different soil depth layers.

The soil of mangrove sites was made up of silt and clay particles. This type of soil shows high water holding capacity, soil aeration and supply of available nutrients (Sheela, 2007). The mean values of percentage of soil particles sand, silt and clay of all the study sites are given in Table 5. The textural study revealed that sand and clay were the predominant fractions at all the sites. The results clearly showed that, the saturation percentage (SP) of soil in the studied areas ranged between $42 \%$ (Sharm EL Madfaa) for A. marina to 55\% (Marsa Abu Fassi) for $R$. mucronata and 52\% (Marsa Abu Fassi) for A. marina / R. mucronata mixed stands with an average of $48.42 \%$ (Table 5). 
Table 5. Descriptive statistics for physical prosperities.

\begin{tabular}{|c|c|c|c|c|c|c|c|c|}
\hline \multirow[b]{2}{*}{ Character } & \multirow{2}{*}{$\begin{array}{c}\begin{array}{c}\text { Sharm } \\
\text { El Madfaa }\end{array} \\
\begin{array}{c}A . \\
\text { marina }\end{array} \\
\end{array}$} & \multicolumn{3}{|c|}{ Marsa Sha'ab } & \multicolumn{3}{|c|}{ Marsa Abu Fassi } & \multirow[b]{2}{*}{ Mean } \\
\hline & & $\begin{array}{c}\text { A. } \\
\text { marina } \\
\text { Pure }\end{array}$ & $\begin{array}{c}\text { R. } \\
\text { mucronata } \\
\text { Pure }\end{array}$ & $\begin{array}{l}\text { Mixed } \\
\text { stands }\end{array}$ & $\begin{array}{c}\text { A. } \\
\text { marina } \\
\text { Pure }\end{array}$ & $\begin{array}{c}R . \\
\text { mucronata } \\
\text { Pure }\end{array}$ & $\begin{array}{l}\text { Mixed } \\
\text { stands }\end{array}$ & \\
\hline Coarse Sand (\%) & 11.5 & 11.5 & 18 & 16 & 15 & 12 & 12.5 & 13.79 \\
\hline Fine Sand (\%) & 38 & 38 & 34 & 35 & 37 & 38 & 36.5 & 36.64 \\
\hline Silt $(\%)$ & 14.5 & 14.5 & 9 & 11.5 & 10.5 & 13.1 & 10.8 & 11.99 \\
\hline Clay $(\%)$ & 36 & 36 & 39 & 37.5 & 37.5 & 36.9 & 36.2 & 37.01 \\
\hline SP & 42 & 45 & 49 & 48 & 48 & 55 & 52 & 48.43 \\
\hline
\end{tabular}

The analyses of the chemical properties of the soil showed that it was slightly alkaline (ranged between 7.7 "Marsa Abu Fassi" for A. marina / R. mucronata mix stands to 7.93 "Marsa Sha'ab" for $R$. mucronata). The EC values of soil extract show variation ranging between $27.9 \mathrm{ds} / \mathrm{m}$ (Sharm EL Madfaa) for A. marina to $51.5 \mathrm{ds} / \mathrm{m}$ (Marsa Sha'ab) for A. marina, the mean value was 39.79. However, mean differences in the soil chemical and physical characters were found in Table 6.

Table 6: Descriptive statistics for Chemical and physical prosperities.

\begin{tabular}{|c|c|c|c|c|c|c|c|}
\hline \multirow[t]{3}{*}{ Character } & \multirow{2}{*}{$\begin{array}{c}\text { Sharm EL } \\
\text { Madfaa } \\
\text { A. } \\
\text { marina }\end{array}$} & \multicolumn{4}{|c|}{ Marsa Sha'ab } & \multicolumn{2}{|c|}{ Marsa Abu Fassi } \\
\hline & & $\begin{array}{c}\text { A. } \\
\text { marina }\end{array}$ & $\begin{array}{c}R . \\
\text { mucrona }\end{array}$ & $\begin{array}{l}\text { Mixed } \\
\text { stands }\end{array}$ & $\begin{array}{c}\text { A. } \\
\text { marina }\end{array}$ & $\begin{array}{c}\text { R. } \\
\text { mucronata }\end{array}$ & $\begin{array}{l}\text { Mixed } \\
\text { stands }\end{array}$ \\
\hline & Pure & Pure & Pure & Mixed & Pure & Pure & Mixed \\
\hline Coarse Sand (\%) & 11.5 & 11.5 & 18 & 6 & 15 & 12 & 12.5 \\
\hline Fine Sand (\%) & 38 & 38 & 34 & 5 & 37 & 38 & 36.5 \\
\hline $\mathrm{pH}$ & 7.89 & 7.88 & 7.93 & 91 & 7.9 & 7.83 & 7.7 \\
\hline $\mathrm{EC}(\mathrm{ds} / \mathrm{m})$ & 27.9 & 51.5 & 40.3 & 38.2 & 36.6 & 44.5 & 39.5 \\
\hline $\mathrm{Na}(\mathrm{meq} / \mathrm{L})$ & 142.5 & 264.6 & 206.6 & 194.5 & 185.8 & 229 & 205 \\
\hline $\mathrm{K}(\mathrm{meq} / \mathrm{L})$ & 1.9 & 2.7 & 2.8 & 2.5 & 2.8 & 3 & 2.9 \\
\hline $\mathrm{Ca}(\mathrm{meq} / \mathrm{L})$ & 70.1 & 130.5 & 102.2 & 97.2 & 92.2 & 113.5 & 103 \\
\hline $\mathrm{HCO} 3$ (meq/L) & 1.9 & 3 & 2.3 & 2 & 2.6 & 2.8 & 2.6 \\
\hline $\mathrm{CaCO}(\%)$ & 8.91 & 22.1 & 23.7 & 16.3 & 29.7 & 30.3 & 29.8 \\
\hline Organic carbon $(\%)$ & 5.2 & 4.8 & 4.4 & 2.9 & 3.2 & 3.1 & 3.1 \\
\hline SP & 42 & 45 & 49 & 48 & 48 & 55 & 52 \\
\hline
\end{tabular}

The total SOC content was statistically higher in the A. marina stands $(39.7 \mathrm{~g} \mathrm{C}$ $\left.\mathrm{kg}^{-1}\right)$ than in the $R$. mucronata stands $\left(33.15 \mathrm{~g} \mathrm{C} \mathrm{kg}^{-1}\right)$ and $\left(32,93 \mathrm{~g} \mathrm{C} \mathrm{kg}^{-1}\right)$ for Mixed stands. However, the organic carbon content ranges of A. marina and $R$. mucronata ranged from $0.3 \%$ to $2.2 \%$ (Table 5 ).

Soil carbonate content showed great variation among the studied stands and ranged between $8.91 \%$ (Sharm EL Madfaa) for A. marina to $30.3 \%$ (Marsa Abu Fassi) for $R$. mucronata, the mean value is $22.97 \%$. Soil calcium contents ranged between $70.1 \mathrm{meq} / \mathrm{L}$ (Sharm EL Madfaa) for A. marina to $130.5 \mathrm{meq} / \mathrm{L}$ (Marsa Sha'ab) for A. marina. Soil magnesium contents showed a range from $63.5 \mathrm{meq} / \mathrm{L}$ (Sharm EL Madfaa) for A. marina to $116.5 \mathrm{meq} / \mathrm{L}$ (Marsa Sha'ab) for A. marina. Soil sodium contents ranged between $142.5 \mathrm{meq} / \mathrm{L}$ (Sharm EL Madfaa) for A. marina to $264.6 \mathrm{meq} / \mathrm{L}$ (Marsa Sha'ab) for A. marina. Soil potassium contents ranged between $1.9 \mathrm{meq} / \mathrm{L}$ (Sharm EL Madfaa) for A. marina to $3 \mathrm{meq} / \mathrm{L}$ (Marsa Abu Fassi) for $R$. mucronata, with the mean value was $2.66 \mathrm{meq} / \mathrm{L}$.

The data indicate that Marsa Sha'ab stands for A. marina recorded the highest value of bicarbonate content $(3 \mathrm{meq} / \mathrm{L})$, but the lowest values were recorded for soil 
of Sharm EL Madfaa stands for A. marina $(1.9 \mathrm{meq} / \mathrm{L})$. The soil collected from Marsa Sha'ab stands for A. marina recorded the highest value of chloride content (492.1 meq/L) while the lowest values were recorded in soil of Sharm EL Madfaa stands $(256.4 \mathrm{meq} / \mathrm{L})$. Soil sulphate contents showed that the highest value was recorded in soil of (Marsa Abu Fassi) stands for A. marina $(52.3 \mathrm{meq} / \mathrm{L})$ and the lowest value was recorded in soil of Marsa Sha'ab stands for $A$. marina (18.9 meq/L).

\section{Ordination}

Detrended Correspondence Analysis (DCA) was used to detect the length of the environmental gradient (Lepŝ and milauer, 2003). Where the DCA analysis reveals information about the range of variation among the stands at the Elba mangrove coastal area (Table 7 and Figure 4).

Table 7. Environmental parameters used in the DCA and their eigenvalues.

\begin{tabular}{|c|c|c|c|c|c|}
\hline Axes & 1 & 2 & 3 & 4 & Total inertia \\
\hline Eigenvalues. & 0.709 & 0 & 0 & 0 & 0.709 \\
\hline Lengths of gradient & 1.414 & 1.414 & 0 & 0 & \\
\hline Species-environment correlations & 1 & 0 & 0 & 0 & \\
\hline $\begin{array}{l}\text { Cumulative percentage variance } \\
\text { of species data }\end{array}$ & 100 & 100.1 & 0 & 0 & \\
\hline $\begin{array}{l}\text { of species-environment relation } \\
\text { Sum of all eigenvalues }\end{array}$ & 100 & 0 & 0 & 0 & 0.709 \\
\hline Sum of all canonical eigenvalues & & & & & 0.709 \\
\hline
\end{tabular}

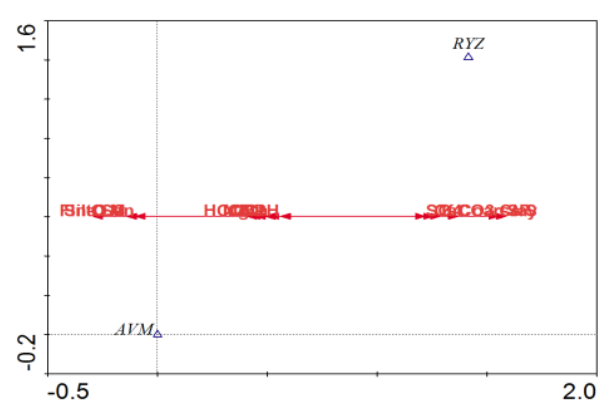

Fig. 4: The species-environment (triangles and circles, respectively) biplot of the DCA of the whole data set in the lower diagram, and retrospective projection of the environmental variables in the upper diagram.

The first gradient is by far the longest one, explaining about $100 \%$ of the total species variability, whereas the second and higher axes explain much less (Table 7 , Figure 4). Also, the first axis is very well correlated with the environmental data $(\mathrm{r}=1)$, and the correlation for the other axis is considerably lower. All this suggests that the whole data set is governed by a single dominant gradient. The sum of all canonical eigenvalues in the printout corresponds to the sum of all canonical eigenvalues in the corresponding canonical analysis. The percentage variance of the species-environment relationship values represents percentages of this value. The number of axis scores calculated for a species-environmental variable biplot is restricted in a DCA, by default, to one. This is why the explained variability for the second, third and fourth axis is shown as 0 . The projection of environmental variables reveals that the first axis is negatively correlated with organic matter and carbon and soil contents (fine sand, silt and clay), with the increasing concentration of $(\mathrm{Mg}++$, electrical conductivity, $\mathrm{pH}$ gradient, $\mathrm{Na}+, \mathrm{Ca}++, \mathrm{Cl}-$ and $\mathrm{Hco} 3-)$, positively correlated with $\left(\mathrm{CaCO}_{3}, \mathrm{~K}+\right.$ and So4--), and with the increasing concentration of soil contents (coarse sand) and The saturation percentage. A closer inspection of the correlation 
matrix in the CANOCO Log View shows that the variables are indeed correlated, but in some cases the correlation is not very great. The correlation matrix also confirms that the correlation of all the measured variables with the second axis is rather weak (Figure 4). Modeling species response curves is used to describe the relationship between a quantity of a particular species and the environmental gradients or gradients of community variation. There is a similarity between the soil samples in different of the study locations as whole area is a coastal. As shown in Figure 5.
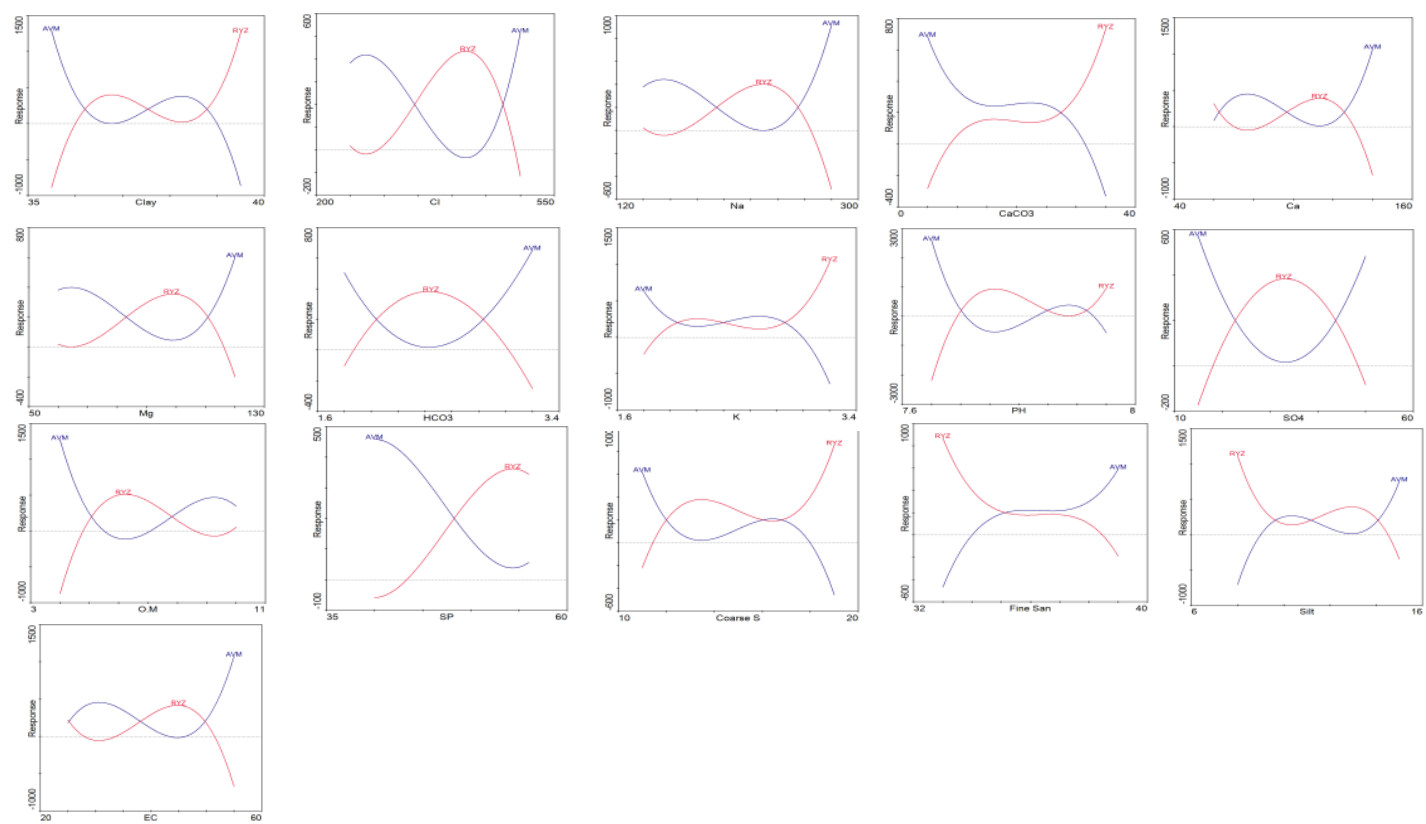

Fig. 5: Important value index of mangrove species in study area against soil parameters.

The current study results showed that both ordination techniques clearly indicated that electric conductivity, $\mathrm{CaCO} 3, \mathrm{~K}+, \mathrm{Ca}++, \mathrm{C} 1-, \mathrm{Na}+$ and $\mathrm{Mg}++$ were the most important parameters for the distribution of the mangrove pattern in the present study.

\section{DISCUSSION}

A. marina usually grows in pure stands, $R$. mucronata may be mixed with $A$. marina as a co-dominant or as an abundant associate, or it may form pure stands. Where both species grow together $R$. mucronata forms an open layer higher than the thick and almost continuous bushy canopy of A. marina (Zahran and Willis, 2009). Mangrove forests are a characteristic feature of the shorelines of the tropical and subtropical seas and oceans, however, their optimum density, diversity and cover is in the wet tropics. Some mangrove swamps occur in the coastlines of the arid areas like those of the Red Sea and Arabian Peninsula's coastal belts (Zahran, 2007).

Through review the literatures, we found that, the mangrove forests distributed along tropical and subtropical coasts are an important ecosystem because of their high net ecosystem production and carbon reserves (Komiyama et al., 2008; Poungparn et al., 2012). Among A. marina tolerates a wider range of salinities (Ball and Farquhar, 1984a, b) and is distributed widely in Africa, Asia, South America, Australia, and Polynesia (Giesen et al., 2006). A. marina trees secrete excessive salt through glands on their leaves (Scholander et al., 1962), and can maintain a higher salinity in xylem 
sap and leaves than non-secreting mangroves, which enhances hydraulic conductivity and reduces osmotic potential (Lopez-Portillo et al., 2005).

To compare the results of the present study with other study in Egyptain Red Sea Mnagrove, EEAA (2009) recorded that, the growth performance of $R$. mucronata was significantly higher in pure stands than in association with A. marina. $R$. mucronata growing in pure population grew twice taller, had more main and lateral branches and attained nearly 4 times the total number of leaves compared with its performance in mixed population with A. marina. However, A. marina trees growing in association with $R$. mucronata were taller than plants growing in pure communities $R$. mucronata stands have the lowest salinity, silt, $\mathrm{pH}$ and $\mathrm{Na}$, but highest of sand and $\mathrm{CaCo3}$. A. marina had the highest values of silt, clay, $\mathrm{pH}, \mathrm{K}$ and $\mathrm{Na}$. $R$. mucrorata contained higher ash. Content $(28.2 \%)$ than A. marina $(18.8 \%)$. The higher values were associated $\mathrm{Cl}, \mathrm{Mg}, \mathrm{Ca}$, and $\mathrm{Na}$.

The Similar results were reported in El-Khouly and Khedr (2007) that, the distribution of both species is subjected to varying condition of salinity concentrations, nutrient levels, substrate structure and tidal movement; however the influence of other environmental factors needs to be analyzed before the current zonation pattern can be properly understood.

We agree with (Thom, 1967; Brooks and Bell, 2005) that, the zonation pattern of the mangroves along the Red Sea coast of Egypt also relates to tidal inundation and morphological characteristics of the species. Rhizophora with extensive prop roots can withstand wave action along the main tidal channels, Avicennia fringe in the less dynamic parts of shores. This confirms that zonation is also a function of habitat change which may be induced by process of landscape evolution. Avicennia cover was greater in the mudflat, with a higher salinity this being a most important factor, along with substrate type and extreme hydrological and oceanographic regimes

Under optimal environmental conditions, A. marina trees form multi-cambia simultaneously at different positions around the stem circumference (Schmitz et al., 2008). This patchy growth mechanism is advantageous in the fluctuating environmental conditions that are driven mainly by climatic and tidal cycles. Due to such physiological and morphological adaptations, A. marina trees growing in inlandwards of a mangrove forests are often dwarfed, whereas those on shoreline fringes are tall and are occasionally highly productive (Naidoo, 2006, 2010).

The study agree with Yoshikawa et al., (2011) as most previous studies have been conducted in tropical areas with a rainy season or in subtropical areas, the water-use characteristics of $A$. marina in per-arid areas remain unknown. Monospecific stands of $A$. marina are found on the Red Sea coast where fresh water is less supplied from inland areas with extremely low rainfall $\left(<70 \mathrm{~mm} / \mathrm{yr}^{1}\right) A$. marina trees in this area have short stems. And lateral branches with attached adventitious roots. This unique morphology is likely related to the water-use habits of leaves in per-arid areas. Carbon isotope compositions of leaf organic matter is a powerful tool for assessment of intrinsic water-use efficiency (Farquhar et al., 1989) relating to salinity (Ball and Farquhar, 1984a, b; Ball, 1988b; Naidoo, 2010). Vivipary Propagules of certain genera contain viviparous seeds which germinate while still attached to the parent tree. When the ripe propagules fall from the parent plant, the seedlings germinate rapidly. Air spaces in the propagules or germinating seedlings are modified to facilitate floating for dispersal by water. These can be found in Rhizophora and Avicennia. The propagules of all mangroves are buoyant and are able to disperse by water (Tomlinson, 1986; Aksornkoae, 1993). 
The soil of A. marina mangrove contains $4.5-19.5 \%$ calcium carbonate whereas that of $R$. mucronata is highly calcareous, containing up to $80 \%$ of its weight of calcium carbonate. The tidal mud of the mangrove vegetation of the Red Sea coast is usually grey or black, and often foul-smelling (Kassas and Zahran, 1967). The total water-soluble salt content ranges from 1.2 to $4.3 \%$. The $\mathrm{pH}$ from 8.5 to 9.0. A notable difference between the tidal mud colonized by A. marina and that by $R$. mucronata is the low content of calcium carbonate in the former (4.5-19.5\%) as compared with the calcareous mud (80\%) in the latter. (Zahran and Willis, 2009).

However, the study agree with El-Khouly and Khedr (2007) who stated that, the habitat of of $R$. mucronata is characterized by low soil salinity, silt and $\mathrm{pH}$ values, compared with that of $A$. marina that grow in more saline habitats and had the highest value of silt. Plots of the association growth of $R$. mucronata and A. marina showed an intermediate values for most of the studied soil variables. The results suggest that while abiotic environmental conditions may account for the absence of $R$. mucronata in high saline mud soils along the Red Sea coast of Egypt, but also the tolerance of each species to each particular is more important in the formation of mixed growth of both species. Moreover, El-Khouly and Khedr (2007) reported that, the distribution pattern and the overlap occurrences of A. marina and $R$. mucronata along the Red Sea coast of Egypt indicate overlap in environmental requirements or tolerance of environmental stress. The mangroves are not restricted to specific soil conditions although each community tends to show niche relation to certain soil variable. Hence, several soil properties could serve as indicators for community type differentiation (Ukpong, 1995). For example, higher acidity (pH-values) prevails in soils associated with Rhizophora communities than Avicennia communities. Rhizophora has extensive fibrous root system which form thick peat-like mud, which lower the $\mathrm{pH}$ after decomposition (Hart, 1962).

In present study, we suggest that, the environmental aspects of mangrove growth in Egypt can be divided into four groups as follows.

I. Climatic conditions.

2. Geomorphological aspects of Red Sea lagoons, bays and islands

3. Water characteristics.

4. Man-made modifications.

Mangroves are sound ecosystems that act as buffer zones to maintain biodiversity along sea-line. The predatory activity of man endangers the inherent fragile nature of this buffer zone. This study taken up against this background along Elba Protected Area shoreline has attempted an in-depth study of mangrove productivity in conjunction with a detailed analysis of water and soil. Mangrove is a tropical formation and its best growth occurs in high temperatures. It seems that individual trees and shrubs, especially of the salt excreting species like A. marina, withstand to some extent dry and hot climate. Mangrove formations along this shoreline are formed mainly of A. marina, a salt-excreting species. Mean maximum temperature $32.2^{\circ} \mathrm{C}$ yearly and $37.5{ }^{\circ} \mathrm{C}$ in summer months (Paramaraj, 2004). Similar observations were reported by Scholander et al. (1962) along the Red Sea coast.

\section{CONCLUSION}

The current study agrees with Zahran and Willis (2009), that the variability of ecosystem structure and function is generally a product of interactions between its different components. In the extreme environmental conditions of arid lands these 
interactions are of high significance, so that slight irregularities in one component of the ecosystem are likely to lead to substantial variations in others, so creating distinct micro habitats. In arid lands, the interrelationships between soils, vegetation and atmosphere are so interconnected that, in an ecological perspective, they can hardly be considered as separate entities.

\section{REFERENCES}

Aksornkoae, S. (1993). Ecology and Management of Mangroves. IUCN Bangkok, Thailand, pp.35-43.

Allen, S.E.; Grimshaw, H.M.; Parkinson, J.A.; Quarmby, C. and Roberts, J.D. (1976). Chemical Analysis of Ecological Materials. Edited by S.B. Chapman. Blackwell Sci. Publ., Oxford. Chapter, 8: 166-411.

Alongi, D. M. (2014). Carbon cycling and storage in mangrove forests. Annual Review of Marine Science, 6. 195-219. Doi. 10.1146/annurev-marine-010213-135020

Ball, M.C. (1988b). Salinity tolerance in the mangroves Aegiceras corniculatum and Avicennia marina. 1. Water-use in relation to growth, carbon partitioning, and salt balance. Aust. J. Plant Physiol., 15: 447-464.

Ball, M.C. and Farquhar, G.D. (1984a). Photosynthetic and stomatal responses of two mangrove species, Aegiceras corniculatum and Avicennia marina, to long-term salinity and humidity conditions. Plant Physiol.,74: 1-6.

Ball, M.C. and Farquhar, G.D. (1984b). Photosynthetic and stomatal responses of the grey mangrove, Avicennia marina, to transient salinity conditions. Plant Physiol., 74: 7-11.

Black, C. A. (1965). Methods of soil analysis. Am. Soc. Agron., pp. 771-1572.

Boto, K.G. and Wellington, J.T. (1984). Soil characteristics and nutrient status in a northern Australian mangrove forest. Estuaries, 7: 61-69.

Brooks, A.R. and Bell, S.S. (2005). A multivariate study of mangrove morphology (Rhizophora mangle) using both above and below-water plant architecture Estuarine, Coastal and Shelf Science, 65: 440-448

Clarke, P.J. (1985). Nitrogen pools and soil characteristics of a temperate estruarine wetland in eastern Australia.Aquat. Bot., 23: 275-290.

Cotnoir, L.J. (1974). Marsh soils of the Atlantic coast. In. Ecology of halophytes. (eds.) Reimold, R.J. and Queen, W.H. Acadernis press, INC. New York. pp.441 -448 .

Crisp, M.D. and Lange, R.T. (1976). Age structure, distribution and survival under grazing of the arid zone shrub Acacia burkitti, 27: 86-92.

Egyptian Environmental Affairs Agency (EEAA) (2009). Assessment and Management of Mangrove Forest in Egypt for Sustainable Utilization and Development. Final report project, funded by The International Tropical Timber Organization, pp.65

El-Khouly, A.A. and Khedr, A.A (2007). Zonation Pattern of Avicennia marina and Rhizophora mucronata along the Red Sea Coast, Egypt. World Applied Sciences Journal, 2(4): 283-288.

FAO (2007). The World's Mangroves 1980-2005, FAO Forestry Paper 153. Rome. Forest Resources Division, FAO. The Food and Agriculture Organisation of the United Nations. $77 \mathrm{p}$.

Farquhar, G.D. ; Ehleringer, J. R. and Hubick, K. T. (1989). Carbon isotope discrimination and photosynthesis. Annu. Rev. Plant Physiol. Plant Mol. Biol., 40: 503-537. 
Gabal Elba Protected Area Staff "GEPA" (2008). Management plan for Elba Protected area. Repot introduced to Nature Conservation Sector, Egyptian Environmental Affairs Agency.

Gamble, J. S. (1921). Flora of the presidency of Madras, Vol. Ito III. London.

Giesen, W.; Wulffraat, S.; Zieren, M. and Scholten, L. (2006). Mangrove guidebook for Southeast Asia. FAO Regional Office for Asia and the Pacific, Bangkok, $539 \mathrm{p}$.

Gillikin, D. and Verheyden, A. (2005). Rhizophora mucronata Lamk. 1804. A field guide to Kenyan mangroves.

Giri, C.; Ochieng, E.; Tieszen, L.L.; Zhu, Z.; Singh, A.; Loveland, T.; Masek, J. and Duke, N. (2011). Status and distribution of mangrove forests of the world using earth observation satellite data (version 1.3, updated by UNEP-WCMC). Global Ecology and Biogeography, 20: 154-159. doi. http.//data.unep-wcmc.org/datasets/4

Hart, M.G.R. (1962). Observation on the source of acid in the empoldered mangrove soils. Formation of elemental sulpher. Plant and Soil, 17: 87-98.

Hejcmanovā-Neźerková, P. and Hejcman, M. (2006). A canonical correspondence analysis (CCA) of the vegetation-environment relationships in Sudanese savannah, Senegal. South African Journal.

Howard, J.; hoyt, S.; Isensee, K.; Telszewski, M. and Pidgeon, E. (eds.) (2014). Coastal blue Carbon. Methods for assessing carbon stocks and emissions factors in mangroves, tidal salt marshes, and seagrasses. Conservation International, Intergovernmental Oceanographic Commission of UNESCO, International Union for Conservation of Nature. Arlington, Virginia, USA.

International Tropical Timber Organization (ITTO) (2006). Egyptian Mangrove Final Report for project of Assessment and Management of Mangrove Forest in Egypt for Sustainable Utilization and Development. Egyptian Environmental Affairs Agency and Ministry of Agriculture and Land Reclamation

Jackson, M.L. (1967). Soil Chemical Analysis-Advanced Course. Washington Department of Soil Sciences, 498pp.

Joshi, G.V. and Jamale, B.B. (1975). Ecological studies in mangroves of Terekhol and Vashistri rivers.Bull. Dep. Mar. Sci. Univ., Cochin., 7: 751-760.

Kassas, M. and Zahran, M.A. (1967). On the ecology of the Red Sea littoral salt marsh, Egypt. Ecol. Monogr., 37(4): 297-315.

Kathiresan, K. and Bingham, B.L. (2001). Biology of mangroves and mangrove ecosystems. Adv. Mar. Biol., 40: 81-251.

Komiyama, A.; Ong, J.E. and Poungparn, S. (2008). Allometry, biomass, and productivity of mangrove forests. a review. Aqua. Bot., 89: 128-137.

Lepŝ, J. and milauer, S. (2003). Multivariate Analysis of Ecological Data Using CANOCO. Cambridge University Press, Cambridge, UK, p. 282.

Lopez-Portillo, J.; Ewers, F.W. and Angeles, G. (2005). Sap salinity effects on xylem conductivity in two mangrove species. Plant Cell Environ., 28: 1285-1292

Muller-Dombois, D. and Ellenberg, H. (1974). Aims and methods of vegetation analysis. New York, John Wiley and Sons, pp. 337.

Naidoo, G. (2006). Factors contributing to dwarfing in the mangrove Avicennia marina. Ann. Bot., 97: 1095-1101.

Naidoo, G. (2010). Ecophysiological differences between fringe and dwarf Avicennia marina mangroves. Trees, 24: 667-673.

Naidoo, G. and Raiman, F. (1982). Some physical and chemical properties of mangrove soils at Sipingo and Mgeni. S. Afr. J. Bot., 1:85-90. 
PERSGA (2004). Status of Mangroves in the Red Sea and Gulf of Aden. Technical Series Number 11, PERSGA, Jeddah, 67 pp. (Prepared by Khalil ASM)

Piper, C. S. (1950). Soil and plant analysis, Univ. of Adelaide press. Australia.

Poungparn, S.; Komiyama, A.; Sangteian, T.; Maknual, C.; Patanaponpaiboon, P. and Suchewaboripont, V. (2012). High primary productivity under submerged soil raises the net ecosystem productivity of a secondary mangrove forest in eastern Thailand. J. Trop. Ecol., 28: 303-306.

Richard, L.A. (1954). Diagnosis and Improvement of saline and Alkaline, Soils. U. S. Department Agr. Handbook, 66 pp.

Schmitz, N.; Robert, E.M.R.; Verheyden, A.; Kairo, J.G.; Beeckman, H. and Koedam, N. (2008). A patchy growth via successive and simultaneous cambia. key to success of the most widespread mangrove species Avicennia marina? Ann. Bot., 101. 49-58.

Scholander, P.F.; Hammel, H.T.; Hemmimgsen, E.A. and Garey, W. (1962). Salt balance in mangrove. Plant Physiol. 37.722- 729.

Sheela Francis, K. (2007). Ecophysiology of Some Species of Mangroves of Kerala Thesis Submitted to the University of Calicut in partial fulfilment of the requirements for the Degree of Doctor Of Philosophy

SPSS (2006). SPSS Base 15.0 User's Guide. SPSS Inc., Chicago

Tan, K.H. (2005). Soil Sampling, Preparation, and Analysis. Taylor and Francis Group, CRC Press, Boca Raton, Florida.

Ter Braak, C.F. (1998). CANOCO. A FORTRAN program for canonica community ordination by partial detrended corresponding analysis principal components analysis and redundancy analysis (Version 2.1 Agric. Math. Wageningen, 95 pp.

Thom, B.G. (1967). Mangrove ecology and deltaic geomorphology. Tabasco, Mexico. J. Ecol., 55: 301-343.

Tomlinson, C.B. (1986). The Botany of Mangroves. Cambridge Tropical Biology Series, Cambridge University Press, Cambridge, New York, USA

U.S. Department of Agriculture [USDA] (1993). Soil Survey Manual. Handbook No. 18. Washington, D.C.

Ukpong, I.E. (1995). An ordination study of mangrove swamp communities in West Africa, Vegetatio, 116: 147-159.

Wilke, B.M. (2005). Determination of chemical and physical soil properties. In. Margesin, R., Schinner, F. (Eds.), Manual for Soil Analysis-Monitoring and Assessing Soil Bioremediation. Springer-Verlag, Heidelberg, pp. 47-95.

Yoshikawa, K.; Inoue, M.; Yoshimori, I.; Nakashima, A.; Teraminami, T.; Matsuo, N.; Banjo, R. and Miyamoto, C. (2011). Forest structure of gray mangrove (Avicennia marina) along Egyptian Red Sea Coast. Sci. Rep. Fac. Agr. Okayama Univ., 100: 39-51.

Zahran, M. A. (2007). Mangrove Ecosystem of the Coastal Belts of the Red Sea and Arabian Peninsula (in Arabic). Zaied International Prize for Environment, Dubai, U. A. E., 330pp.

Zahran, M.A. and Al-Kaf, H. F. (1996). Introduction to the ecology of the littoral halophytes of Yemen. Arab. Gulf. J. Sci. Res., 14: 691-703.

Zahran, M. A. and Willis, A. J. (2009). The vegetation of Egypt. Springer, $2^{\text {nd }}$ edition, 437pp. 